\title{
Inhibition Performance and Adsorption Behavior of Spinacia Oleracea Leaves Extracts on Mild Steel Corrosion in Hydrochloric Acid Medium
}

\author{
S.S. SHIVAKUMAR, K.N. MOHANA* and D.M. GURUDATT \\ Department of Chemistry, University of Mysore, Mysore - 570006, India \\ drknmohana@gmail.com
}

Received 12 July 2012 / Accepted 16 August 2012

\begin{abstract}
Alcoholic extracts of Spinach (SP) leaves was studied as corrosion inhibitor for mild steel in $0.5 \mathrm{M} \mathrm{HCl}$ using weight loss, potentiodynamic polarization and electrochemical impedance spectroscopy techniques. The results of the study revealed that $S P$ extracts inhibit mild steel corrosion through adsorption process following Langmuir adsorption isotherm. The protection efficiency increased with increase in inhibitor concentration and decreased with temperature. Polarization measurements indicated that the $S P$ behaves as mixed type of inhibitor. EIS measurements showed that the charge transfer resistance increases with increase in the concentration of SP extracts. Various thermodynamic parameters such as activation energy, activation enthalpy and activation entropy were evaluated. Adsorption thermodynamic parameters were also computed and SEM was used to analyze the surface adsorbed film.
\end{abstract}

Keywords: Mild steel, Spinach leaves extracts, Corrosion, Polarization, Impedance

\section{Introduction}

Mild steel is the most widely used material particularly in mechanical engineering, transportation industry and construction industry. Corrosion problem occurs in these industries and can cause disastrous damage to metal and alloy structures causing economic consequences in terms of repair, replacement and product losses. Therefore, a wide variety of corrosion inhibitors ranging from rare earth elements ${ }^{1,2}$ to organic compounds ${ }^{3-6}$ have been used. Most of the efficient inhibitors used in industries are organic compounds having multiple bonds in their molecules which contain $\mathrm{N}$ and $\mathrm{S}$ atoms ${ }^{7-8}$. These inhibitors may cause reversible or irreversible damage to organ system or may disturb a biochemical processes or to disturb an enzyme system at the same site in the body. These toxic effects have led to the use of natural products as anticorrosion agents which are eco-friendly and harmless. Further, the known hazardous effects of most synthetic corrosion inhibitors are the motivation for the use of some natural products. Plant extracts have become important as an environmentally acceptable readily available and renewable source for a wide range of corrosion inhibitors ${ }^{9}$. Plant extracts are viewed as an incredibly rich source of naturally 
synthesized chemical compounds that can be extracted by simple procedures with low cost. Recently, several natural compounds such as, Azadirachta indica ${ }^{10}$, Isertia coccinea ${ }^{11}$, Prosopis cineraria ${ }^{12}$, Hibiscus sabdariffa extract ${ }^{13}$, Clematis gouriana ${ }^{14}$, Aloe vera extract ${ }^{15}$, Phyllantus amarus extracts ${ }^{16}$, Dacroydes edulis ${ }^{17}$, Murraya koenigii ${ }^{18}$, Foeniculum vulgare $^{19}$, Chlomolaena odorata $\mathrm{L}^{20}$, Radish ${ }^{21}$ and Jasminum nudiflorum ${ }^{22}$ have been reported as effective corrosion inhibitors for metals in acidic, alkaline and neutral solutions.

Spinach (Spinacia oleracea) is an edible plant in the family of Amaranthaceae. It is one of the most important antioxidant vegetable and it is an excellent source of several flavonoids, vitamin $\mathrm{C}$, vitamin $\mathrm{A}$, iron and potassium ${ }^{23}$. In the light of the available information, the present paper reports the result of our investigation on the inhibitive performance of spinach extracts as green corrosion inhibitor on mild steel at different temperature in $0.5 \mathrm{M} \mathrm{HCl}$ solution using gravimetric, potentiodynamic polarization and electrochemical impedance methods. The adsorption thermodynamic parameters were evaluated and isotherm behavior has been determined.

\section{Experimental}

Corrosion tests were performed on mild steel having the following composition (in wt\%) 0.016 P, $0.322 \mathrm{Si}, 0.01 \mathrm{Al}, 0.062 \mathrm{Cr}, 0.05 \mathrm{Mn}, 0.09 \mathrm{C}, 0.05 \mathrm{~S}$ and the remainder iron (Fe). Prior to gravimetric and electrochemical measurements, the surface of the specimens was polished under running tap water using SiC emery paper (grade 220-600), rinsed with distilled water, dried on a clean tissue paper, immersed in benzene for $5 \mathrm{~s}$, dried and immersed in acetone for $5 \mathrm{~s}$ and dried with clean tissue paper. Finally, the specimens were kept in desiccators until use. At the end of the test, the specimens were carefully washed with acetone and benzene, dried and then weighed.

Fresh Spinach leaves were collected in and around Mysore city, cleaned with water and then dried in an oven at $60{ }^{\circ} \mathrm{C}$ and ground to powder. The $10 \mathrm{~g}$ of the powder sample was refluxed in $250 \mathrm{~mL}$ ethyl alcohol for $5 \mathrm{~h}$. The refluxed solution was filtered and the filtered liquor was evaporated to $100 \mathrm{~mL}$ dark green residue and then degreased with petroleum ether and extracted with separating funnel. The solution was evaporated and the dark green solid residue obtained after complete drying was preserved in a desiccator. The residue so obtained was used in preparing different concentrations of the extracts in $0.5 \mathrm{M} \mathrm{HCl}$ solution.

Pre-weighed mild steel coupons with a dimension of $2 \times 2 \times 0.3 \mathrm{~cm}$ were immersed in $200 \mathrm{~mL} \mathrm{HCl}$ with and without the addition of different concentrations of SP extracts in an aerated condition. After $6 \mathrm{~h}$ of immersion, the specimens were taken out, washed, dried and weighed accurately. Experiments were carried out in triplicate. The average weight loss of the three parallel specimens was obtained. Relative weight losses of the coupons were used to calculate the percent inhibition efficiency, $\eta \%$. Then the tests were repeated with different concentrations of $S P$ at varying temperatures.

Polarization and EIS experiments were carried out using a CHI660D electrochemical workstation. A conventional three-electrode cell consisting of a saturated calomel reference electrode, a platinum auxiliary electrode and the working electrode with $1 \mathrm{~cm}^{2}$ exposed areas was used. The specimens were pre-treated similarly as done in the gravimetric measurements. The electrochemical tests were performed using various SP extracts concentrations ranging from 0 to $2000 \mathrm{ppm}$ at $30^{\circ} \mathrm{C}$ using a thermostatically controlled water bath (Weiber, India) under aerated condition. Potentiodynamic polarization measurements were performed in the potential range from -900 to $+500 \mathrm{mV}$ with a scan rate of $0.4 \mathrm{mV} \mathrm{s}^{-1}$. The AC impedance measurements were performed in the frequency range of 10 to $0.05 \mathrm{kHz}$ with signal amplitude of $\pm 10 \mathrm{mV}$. 


\section{Results and Discussion}

\section{Weight loss measurements}

The corrosion rate of mild steel immersed in $0.5 \mathrm{M} \mathrm{HCl}$ solutions at different temperatures as a function of $S P$ extracts concentration are shown in Figure 1. The corrosion rate decreases as the concentration of $S P$ extracts increases up to $2000 \mathrm{ppm}$. Above $2000 \mathrm{ppm}$, the corrosion rate approximately remained constant. This can be attributed to the increase in adsorption of the $S P$ extracts molecules onto the mild steel surface ${ }^{24}$. Above $2000 \mathrm{ppm}$, the constant rate obtained could be attributed to the competitive adsorption effect between inhibitor molecules and the metal surface (which is already covered with initial layers of molecules). The corrosion rate was calculated using the equation given below,

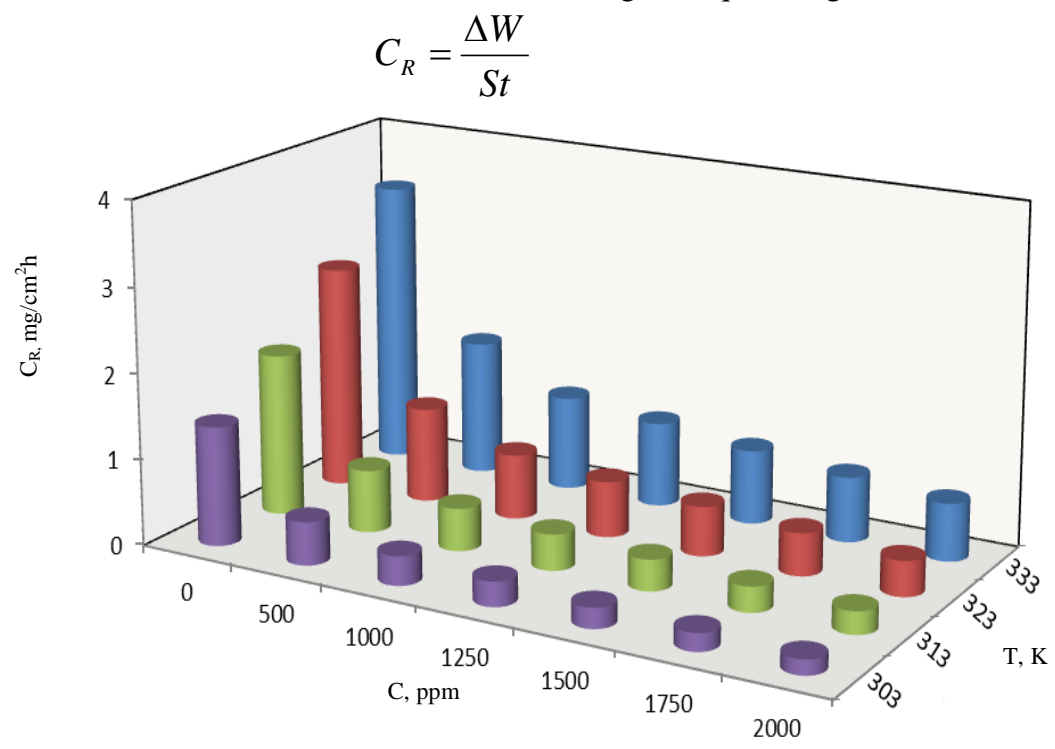

Figure 1. Variation of $C_{\mathrm{R}}$ as a function of temperature and concentration of $S P$ extracts

Where, $\Delta W$ is the weight loss, $S$ is the surface area of the specimen $\left(\mathrm{cm}^{2}\right)$ and $t$ is immersion time (h). With the calculated corrosion rate, the inhibition efficiency ( $\eta \%)$ was calculated as follows:

$$
\eta \%=\frac{\left(C_{R}\right)_{a}-\left(C_{R}\right)_{p}}{\left(C_{R}\right)_{a}} \times 100
$$

Where $\left(C_{\mathrm{R}}\right)_{\mathrm{a}}\left(C_{\mathrm{R}}\right)_{\mathrm{p}}$ are corrosion rates in the absence and presence of the inhibitor, respectively.

\section{Effect of immersion time}

In order to evaluate the effect of immersion time on inhibitive behavior of the $S P$ extracts, weight loss measurements were performed in $0.5 \mathrm{M} \mathrm{HCl}$ in the absence and presence of $2000 \mathrm{ppm}$ extracts for 2 to $10 \mathrm{~h}$ immersion time at $303 \mathrm{~K}$. Figure 2 shows that the inhibition efficiency of the extracts was increased with increasing immersion time from 2 to $6 \mathrm{~h}$ but after $6 \mathrm{~h}$, inhibition efficiency slightly decreases. The increase in inhibition efficiency up to $6 \mathrm{~h}$ indicates the adsorption of constituents present in the extracts on the mild steel surface, resulting in the formation of more protective layer at metal - acid interface. Furthermore, with time, it 
seems that inhibiting effect decreases probably because some defects exist on the film leading to the access of aggressive anions to the metal - acid interface. Thus, SP leaves extracts effectively inhibits the mild steel corrosion in $0.5 \mathrm{M}$ hydrochloric acid solution at $6 \mathrm{~h}$ immersion.

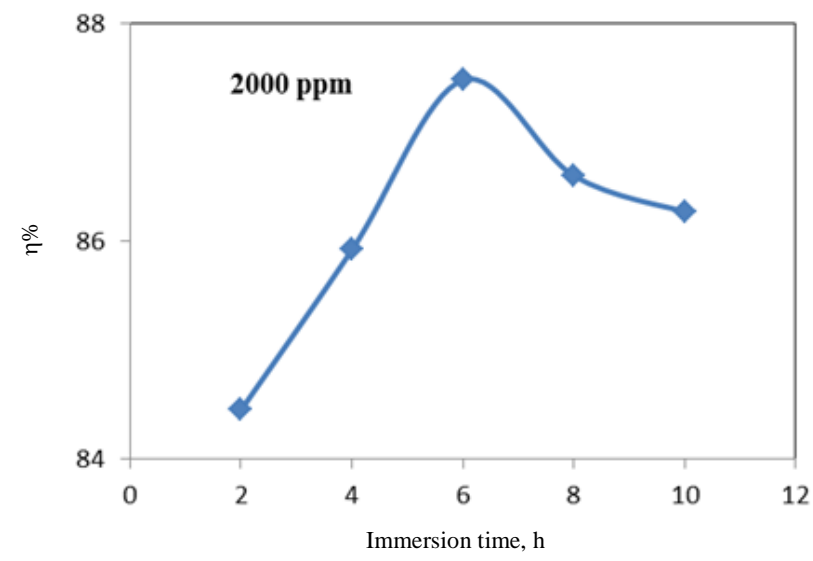

Figure 2. Variation of inhibition efficiency ( $\eta \%)$ on the corrosion of mild steel as function of immersion time in $0.5 \mathrm{M} \mathrm{HCl}$ in the presence of $2000 \mathrm{ppm} \mathrm{SP}$ extracts at $30{ }^{\circ} \mathrm{C}$

\section{Effect of temperature}

The activation parameters play an important role in understanding the inhibitive mechanism of the inhibitor. Results of $\eta \%$ obtained at different temperatures (Table 1 ) reveal that, increasing temperature increases the corrosion rate and reduces the $\eta \%$ at all studied concentrations. Such trend implies that this compound is adsorbed physically on mild steel surface and the extent of adsorption decreases with raising temperature.

Table 1. $C_{\mathrm{R}}$ and $\eta \%$ obtained from weight loss measurements of mild steel in $0.5 \mathrm{M} \mathrm{HCl}$ containing various concentrations of $S P$ extract at different temperatures

\begin{tabular}{|c|c|c|c|c|c|c|c|c|}
\hline \multicolumn{9}{|c|}{ Temperature } \\
\hline \multirow{2}{*}{$\begin{array}{c}C, \\
\mathrm{ppm}\end{array}$} & \multicolumn{2}{|c|}{$30^{\circ} \mathrm{C}$} & \multicolumn{2}{|c|}{$40^{\circ} \mathrm{C}$} & \multicolumn{2}{|c|}{$50^{\circ} \mathrm{C}$} & \multicolumn{2}{|c|}{$60^{\circ} \mathrm{C}$} \\
\hline & $\begin{array}{c}C_{\mathrm{R}}, \\
\mathrm{mg} / \mathrm{cm}^{2} \mathrm{~h}\end{array}$ & $\eta \%$ & $\begin{array}{c}C_{\mathrm{R}}, \\
\mathrm{mg} / \mathrm{cm}^{2} \mathrm{~h}\end{array}$ & $\eta \%$ & $\begin{array}{c}C_{\mathrm{R}}, \\
\mathrm{mg} / \mathrm{cm}^{2} \mathrm{~h}\end{array}$ & $\eta \%$ & $\begin{array}{c}C_{\mathrm{R}}, \\
\mathrm{mg} / \mathrm{cm}^{2} \mathrm{~h}\end{array}$ & $\eta \%$ \\
\hline 0 & 1.394 & - & 1.898 & - & 2.628 & - & 3.351 & - \\
\hline 500 & 0.503 & 63.92 & 0.730 & 61.52 & 1.114 & 57.61 & 1.591 & 52.52 \\
\hline 1000 & 0.339 & 75.68 & 0.498 & 73.75 & 0.762 & 71.01 & 1.106 & 66.99 \\
\hline 1250 & 0.286 & 79.48 & 0.423 & 77.71 & 0.653 & 75.15 & 0.993 & 70.37 \\
\hline 1500 & 0.236 & 83.07 & 0.363 & 80.87 & 0.578 & 77.99 & 0.869 & 74.07 \\
\hline 1750 & 0.206 & 85.22 & 0.295 & 84.46 & 0.498 & 81.06 & 0.764 & 77.21 \\
\hline 2000 & 0.175 & 87.48 & 0.261 & 86.25 & 0.411 & 84.37 & 0.674 & 79.89 \\
\hline
\end{tabular}

The apparent activation energy for the corrosion process of mild steel in $0.5 \mathrm{M} \mathrm{HCl}$ solution in the absence and presence of different concentrations $S P$ extracts were calculated from the slopes of the linear plots of $\log C_{R} v s .1 / T$ (Figure 3) using the following Arrheniustype equation,

$$
C_{R}=A \exp \left(-\frac{E_{a}^{*}}{R T}\right)
$$




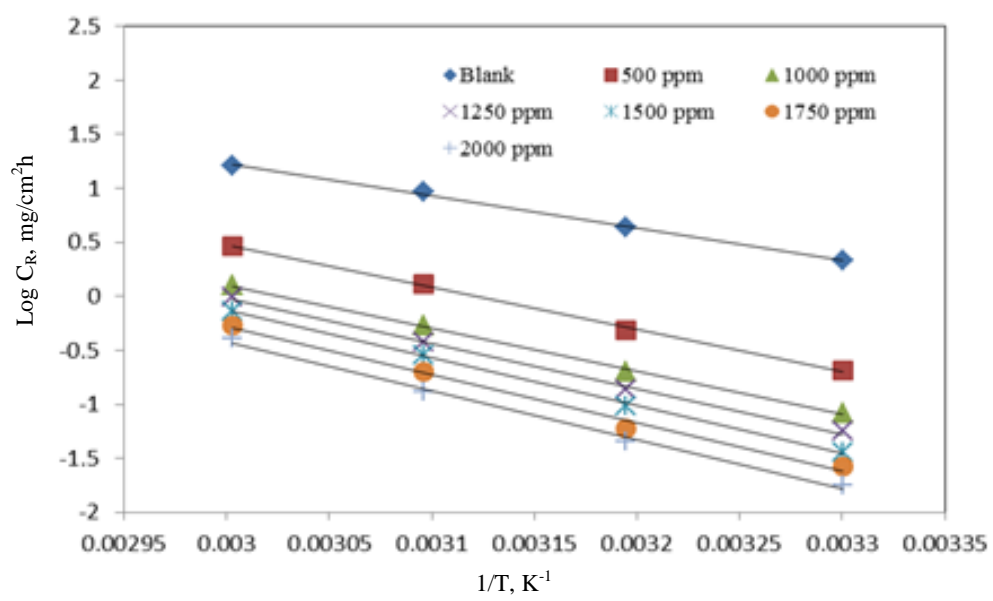

Figure 3. Arrhenius plots for the corrosion of mild steel in $0.5 \mathrm{M} \mathrm{HCl}$ in the absence and presence of different concentrations $S P$ extracts

Where $E_{\mathrm{a}}{ }^{*}$ is the apparent activation energy, $T$ is the absolute temperature, $A$ is the Arrhenius pre-exponential constant and $R$ is the universal gas constant. It can be seen in Table 2 that activation energy for inhibited solutions are high compared to the blank suggests that the mechanism of adsorption of inhibitor on mild steel surface is by physical adsorption. Higher values of $E_{\mathrm{a}}{ }^{*}$ in the inhibited systems compared to the blank suggests a physical adsorption mechanism ${ }^{25-27}$, while unchanged or lower values of $E_{\mathrm{a}}{ }^{*}$ indicate the chemisorption mechanism ${ }^{28-29}$. Enthalpy and entropy of activation were calculated by using the alternative form of Arrhenius equation given below,

$$
C_{R}=\frac{R T}{N h} \exp \frac{\Delta S^{*}}{R} \exp \left(-\frac{\Delta H^{*}}{R T}\right)
$$

Table 2. Activation parameters for mild steel in $0.5 \mathrm{M} \mathrm{HCl}$ in the absence and presence of different concentrations of $S P$ extracts

\begin{tabular}{cccccc}
\hline $\begin{array}{c}C \\
\mathrm{ppm}\end{array}$ & $\begin{array}{c}E_{\mathrm{a}}{ }^{*} \\
\mathrm{~kJ} / \mathrm{mol}\end{array}$ & $k$ & $\begin{array}{c}\Delta H^{*} \\
\mathrm{~kJ} / \mathrm{mol}\end{array}$ & $\begin{array}{c}\Delta H^{*}=E_{a}{ }^{*}-R T \\
\mathrm{~kJ} / \mathrm{mol}\end{array}$ & $\begin{array}{c}\Delta S^{*} \\
\mathrm{~J} / \mathrm{mol} \mathrm{K}\end{array}$ \\
\hline 0 & 24.82 & 26370 & 22.18 & 21.97 & -169.06 \\
500 & 32.51 & 198789 & 29.86 & 29.66 & -152.29 \\
1000 & 33.31 & 206901 & 30.67 & 30.45 & -152.93 \\
1250 & 34.93 & 293607 & 32.29 & 32.08 & -149.06 \\
1500 & 36.70 & 493856 & 34.05 & 33.85 & -144.74 \\
1750 & 37.30 & 529665 & 34.66 & 34.45 & -144.12 \\
2000 & 37.74 & 534988 & 35.10 & 34.89 & -144.06 \\
\hline
\end{tabular}

Where $h$ is Planck's constant and $N$ is Avogadro's number. The plots of $\log \left(C_{\mathrm{R}} / T\right) v s$. $1 / T$ for mild steel in $0.5 \mathrm{M} \mathrm{HCl}$ solution in the absence and presence of various concentrations of $S P$ extracts gave straight lines as shown in Figure 4. The values of $\Delta H^{*}$ and $\Delta S^{*}$ were calculated from the slopes and intercepts, respectively and are listed in Table 2 . Inspection of Table 2 revealed that, the positive value of $\Delta H^{*}$ reflects the endothermic nature of the mild steel dissolution process ${ }^{30}$, while the values of $\Delta S^{*}$ indicate that an increase in disordering takes place on going from reactant to the activated complex ${ }^{31}$. 


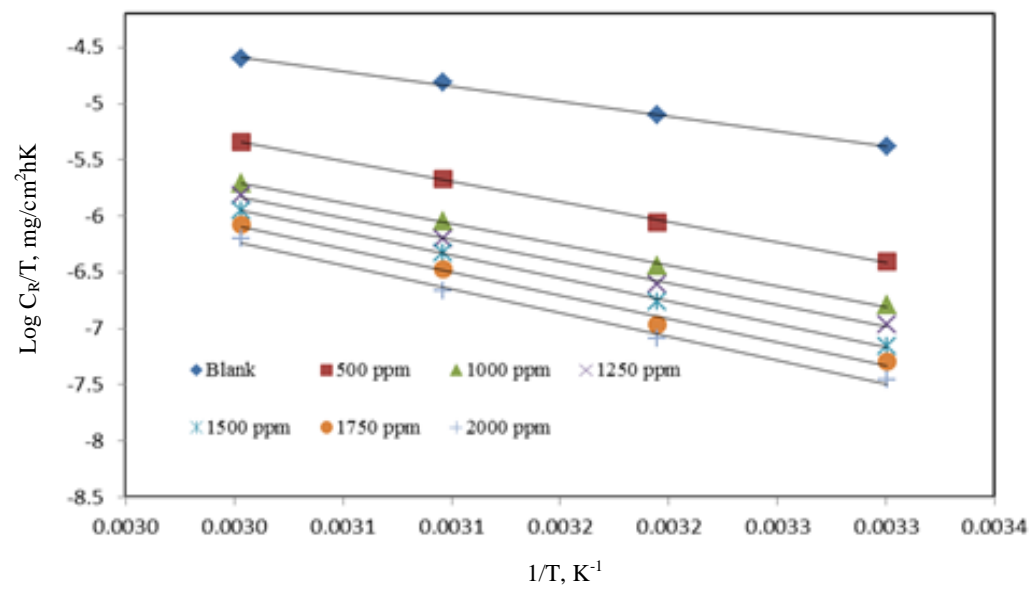

Figure 4. Alternative Arrhenius plots for mild steel dissolution in $0.5 \mathrm{M} \mathrm{HCl}$ in the absence and presence of different concentrations of SP extracts

\section{Adsorption studies}

The dependence of degree of surface coverage $(\theta)$ as a function of inhibitor's concentration $(C)$ was tested graphically by fitting it to various isotherms to find the best isotherm which describes this study. All these isotherms are of the general form,

$$
\int(\theta, \chi) \exp (2 \alpha \theta)=K_{a d s} C
$$

Where $\int(\theta, x)$ is the configurational factor which depends upon the physical model and the assumptions underlying the derivation of the isotherm. $\alpha$ is the lateral interaction term describing the molecular interactions between the adsorbed layer and heterogeneity of the surface. $K_{\text {ads }}$ is the adsorption-desorption equilibrium constant.

Figures 5, 6 and 7 represent fitting of weight loss data obtained for mild steel in $0.5 \mathrm{M} \mathrm{HCl}$ containing various concentrations of $S P$ extracts to Langmuir, Frumkin and Temkin isotherms.

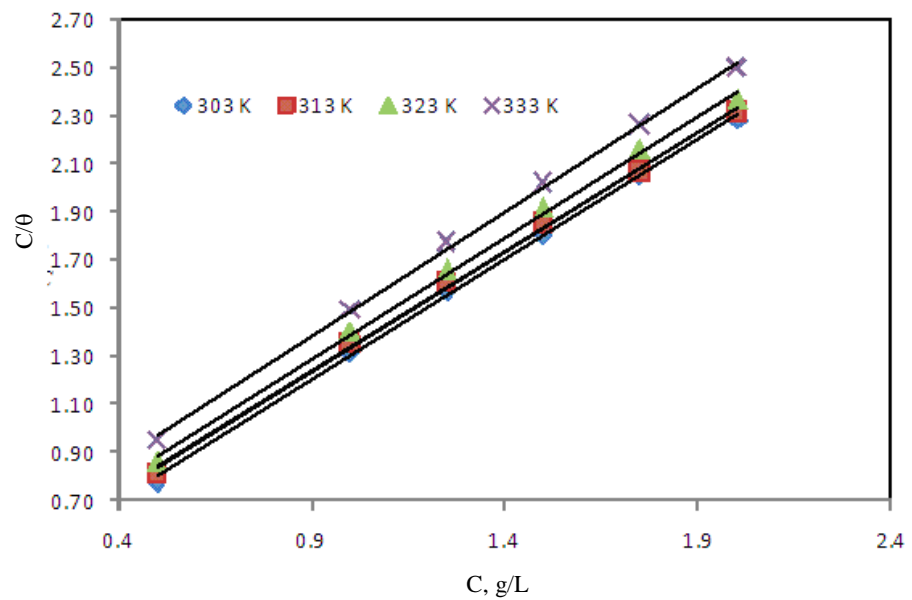

Figure 5. Langmuir isotherm for the adsorption of $S P$ on mild steel surface in $0.5 \mathrm{M} \mathrm{HCl}$ at different temperatures 


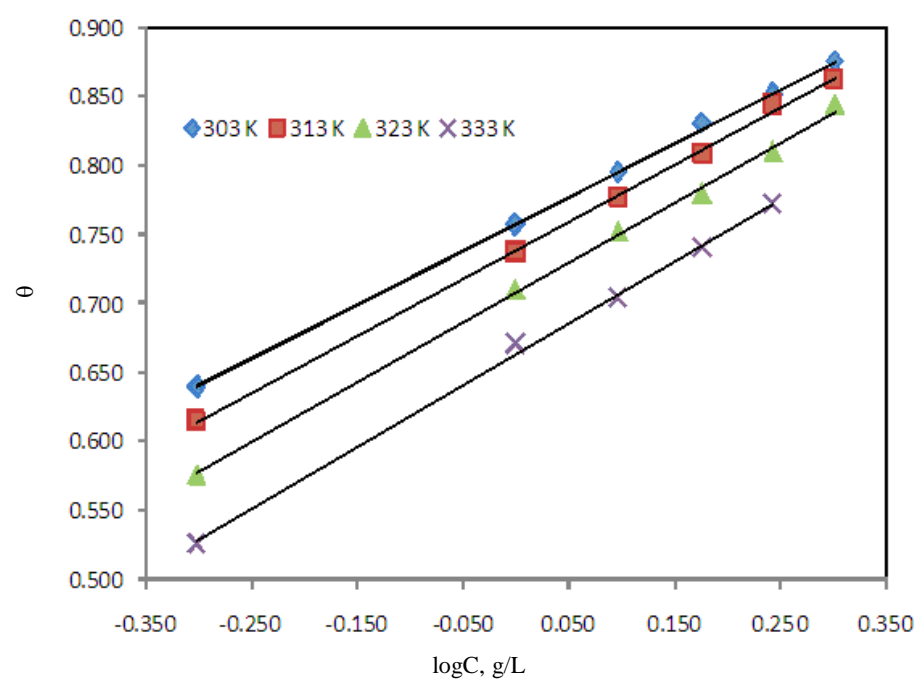

Figure 6. Temkin isotherm for the adsorption of $S P$ on mild steel surface in $0.5 \mathrm{M} \mathrm{HCl}$ at different temperatures

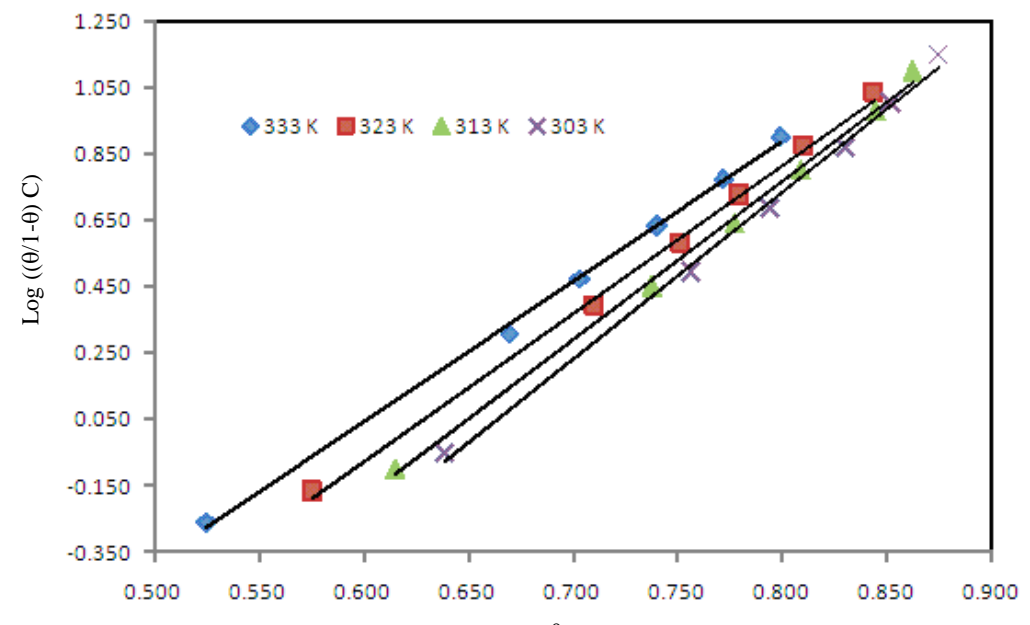

Figure 7. Frumkin isotherm for the adsorption of $S P$ on mild steel surface in $0.5 \mathrm{M} \mathrm{HCl}$ at different temperatures

$$
\begin{array}{ll}
\frac{c}{\theta}=\frac{1}{K_{a d s}}+c & \text { (Langmuir isotherm) } \\
\left(\frac{\theta}{1-\theta}\right) \exp (-2 \alpha \theta)=K C & \text { (Frumkin isotherm) } \\
\exp (-2 \alpha \theta)=K C & \text { (Temkin isotherm) }
\end{array}
$$

The values of correlation coefficient $\left(R^{2}\right)$ were used to judge the best fit isotherm. In the present study, it is found that the data obtained can be fitted to Langmuir, Frumkin and Temkin isotherm models but Langmuir adsorption isotherm was the best one. 
The plot of $C / \theta$ vs. $C$ gave a straight line (Figure 5) with a slope close to unity confirming that the adsorption of SP extracts on mild steel surface in hydrochloric acid obeys the Langmuir adsorption isotherm. $K_{\text {ads }}$ is related to the standard Gibb's free energy of adsorption $\Delta G_{\text {ads }}$ according to the following equation:

$$
K_{a d s}=\frac{1}{55.5} \exp \left(\frac{-\Delta G_{a d s}}{R T}\right)
$$

Where $\mathrm{R}$ is the universal gas constant, $T$ is the absolute temperature and 55.5 is the concentration of water in solution $\left(\mathrm{mol} \mathrm{L}^{-1}\right)$. This isotherm is based on the assumption that the solid surface contains a fixed number of adsorption sites and each site holds one adsorbed species ${ }^{32}$. By using equation (9), the calculated $\Delta G_{\text {ads }}$ valves are tabulated in Table 3. The negative sign of $\Delta G_{\text {ads }}$ demonstrates that the inhibitor is spontaneously adsorbed on to the metal surface. Normally, the magnitude of $\Delta G_{\text {ads }}$ around $-20 \mathrm{~kJ} \mathrm{~mol}^{-1}$ or less negative is consistent with electrostatic interaction exit between inhibitor and charged metal surface (physisorption) ${ }^{33}$ whereas $-40 \mathrm{~kJ} \mathrm{~mol}^{-1}$ or more negative are indication of chemisorption ${ }^{34}$. The entropy of adsorption can be calculated based on the following thermodynamic equation,

$$
\Delta G_{\mathrm{ads}}=\Delta H_{\mathrm{ads}}-T \Delta S_{\mathrm{ads}}
$$

Table 3. Thermodynamic parameters for adsorption of $S P$ extracts on mild steel in $0.5 \mathrm{M}$ $\mathrm{HCl}$ at different temperatures from Langmuir adsorption isotherm

\begin{tabular}{ccccccc}
\hline $\begin{array}{c}\text { Temperature } \\
\mathrm{K}\end{array}$ & $\mathrm{R}^{2}$ & $\begin{array}{c}K_{\text {ads }} \\
\mathrm{L} / \mathrm{mol}\end{array}$ & $\begin{array}{c}\Delta G_{\text {ads }} \\
\mathrm{kJ} / \mathrm{mol}\end{array}$ & $\begin{array}{c}\Delta H_{\text {ads }} \\
\mathrm{kJ} / \mathrm{mol}\end{array}$ & $\begin{array}{c}\Delta S_{\text {ads }} \\
\mathrm{J} / \mathrm{mol} \mathrm{K}\end{array}$ & $\begin{array}{c}\Delta G_{\mathrm{ads}}=\Delta H_{\mathrm{ads}}-T \Delta S_{\text {ads }} \\
\mathrm{kJ} / \mathrm{mol}\end{array}$ \\
\hline 303 & 0.999 & 3.2894 & -13.12 & & & -13.28 \\
313 & 0.998 & 2.9411 & -12.84 & -23.28 & -33.00 & -12.95 \\
323 & 0.998 & 2.5773 & -12.50 & & & -12.62 \\
333 & 0.998 & 2.2075 & -12.11 & & & -12.29 \\
\hline
\end{tabular}

Using equation (10) and from a plot of $\Delta G_{\text {ads }} v s . T$ (Figure 8), the values of $\Delta S_{\text {ads }}$ and $\Delta H_{\text {ads }}$ were computed from slopes and intercepts, respectively and the results are presented in Table 3. The values of $\Delta S_{\text {ads }}$ and $\Delta H_{\text {ads }}$ give information about the mechanism of corrosion. The negative value of $\Delta H_{\text {ads }}$ indicates that adsorption process is exothermic. An exothermic adsorption process may be chemisorption or physisorption or mixture of both ${ }^{35}$, whereas endothermic process is attributed to chemisorption ${ }^{36}$. In exothermic adsorption process, physisorption can be distinguished from the chemisorptions on the basis of values of $\Delta H_{\text {ads }}$. For physisorption process the magnitude of $\Delta H_{\mathrm{ads}}$ is around - $40 \mathrm{~kJ} \mathrm{~mol}^{-1}$ or less negative while its value $-100 \mathrm{~kJ} \mathrm{~mol}^{-1}$ or more negative for chemisorption ${ }^{37}$. In the present work, the value of $\Delta H_{\text {ads }}$ indicates that the $S P$ extracts adsorb on the mild steel surface through physisorption.

\section{Potentiodynamic polarization}

The potentiodynamic polarization curves obtained from the corrosion behavior of mild steel in $0.5 \mathrm{M} \mathrm{HCl}$ in the absence and presence of $S P$ extracts are shown in Figure 9. The electrochemical parameters such as corrosion potential $\left(E_{\text {corr }}\right)$ and corrosion current density $\left(I_{\text {corr }}\right)$ obtained from the polarization measurements are listed in Table 4 . The $\eta \%$ was calculated using the following equation:

$$
\eta \%=\frac{\left(I_{\text {corr }}\right)_{a}-\left(I_{\text {corr }}\right)_{p}}{\left(I_{\text {corr }}\right)_{a}} \times 100
$$




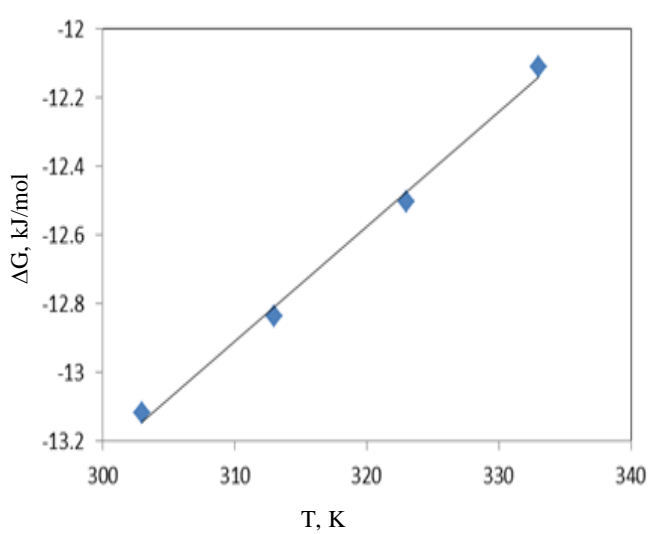

Figure 8. Plot of $\Delta G_{\text {ads }} v s$. absolute temperature

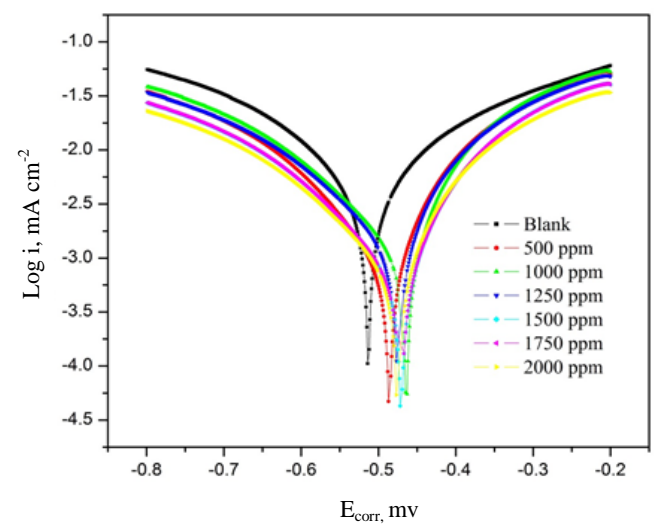

Figure 9. Polarization curves in the absence and presence of different concentrations of $S P$ extracts in $0.5 \mathrm{M} \mathrm{HCl}$

Table 4. $E_{\text {corr }}, I_{\text {corr, }} R_{\mathrm{ct}}$ and $\eta \%$ obtained from polarization and impedance measurements for mild steel in $0.5 \mathrm{M} \mathrm{HCl}$ containing various concentrations of $S P$ extracts at $30{ }^{\circ} \mathrm{C}$

\begin{tabular}{|c|c|c|c|c|c|}
\hline \multirow{2}{*}{$C$, ppm } & \multicolumn{2}{|c|}{ EIS } & \multicolumn{3}{|c|}{ Polarization } \\
\hline & $R_{\mathrm{ct}}, \Omega \mathrm{cm}^{2}$ & $\eta \%$ & $E_{\text {corr }}, \mathrm{mV}$ & $I_{\text {corr }}, \mathrm{mA} / \mathrm{cm}^{2}$ & $\eta \%$ \\
\hline 0 & 18.42 & - & -513 & 4.84 & - \\
\hline 500 & 57.03 & 67.70 & -456 & 1.603 & 66.88 \\
\hline 1000 & 66.21 & 72.18 & -459 & 1.322 & 72.69 \\
\hline 1250 & 77.82 & 76.33 & -465 & 1.163 & 75.97 \\
\hline 1500 & 119.70 & 84.61 & -474 & 0.751 & 84.48 \\
\hline 1750 & 129.10 & 85.73 & -479 & 0.721 & 85.10 \\
\hline 2000 & 135.80 & 86.44 & -472 & 0.643 & 86.71 \\
\hline
\end{tabular}

Where, $\left(I_{\text {corr }}\right)_{\mathrm{a}}$ and $\left(I_{\text {corr }}\right)_{\mathrm{p}}$ are the corrosion current density $\left(\mathrm{mA} \mathrm{cm}^{-2}\right)$ in the absence and presence of the inhibitor, respectively. From the potentiodynamic polarization curves, it can be clearly seen that, as the concentration increases both anodic and cathodic curves were shifted toward the lower current density. This phenomenon implies that the inhibitor could suppress anodic reaction of the metal dissolution as well as cathodic hydrogen evolution ${ }^{38}$.

In the presence of inhibitor, the $E_{\text {corr }}$ of mild steel shifted towards anodic region compared to the blank. This indicates that the inhibitor reduces the corrosion rate predominantly by anodic mode. The inhibitor may shift the equilibrium of corrosion process to the passive direction resulting in the formation of a thin passivation oxide film over the anodic sites, which may increase the anodic potential and suppress the oxidation process. Ferreira and others ${ }^{39-40}$ reported that, if the deviation in the $E_{\text {corr }}$ is greater than $85 \mathrm{mV}$ in inhibited system with respect to uninhibited, the inhibitor could be recognized as cathodic or anodic type whereas the deviation in $E_{\text {corr }}$ less than $85 \mathrm{mV}$, it could be recognized as mixed type of inhibitor. In the present investigation, the maximum deviation range is less than $85 \mathrm{mV}$ which reveals that $S P$ extracts acts as mixed type of inhibitor.

\section{Electrochemical impedance spectroscopy}

Electrochemical impedance spectroscopy is a powerful tool in the investigation of the corrosion and adsorption phenomena. The Nyquist plots for mild steel in $0.5 \mathrm{M} \mathrm{HCl}$ in the 
absence and presence of $S P$ extracts are shown in Figure 10. Nyquist impedance plots were analyzed by fitting the experimental data to a simple circuit model (Figure 11) that includes the solution resistance $\left(R_{\mathrm{s}}\right)$, charge transfer resistance $\left(R_{\mathrm{ct}}\right)$ and double layer capacitance $\left(C_{\mathrm{dl}}\right)$. The values are presented in Table 4 . The $\eta \%$ was calculated using the charge transfer resistance as follows,

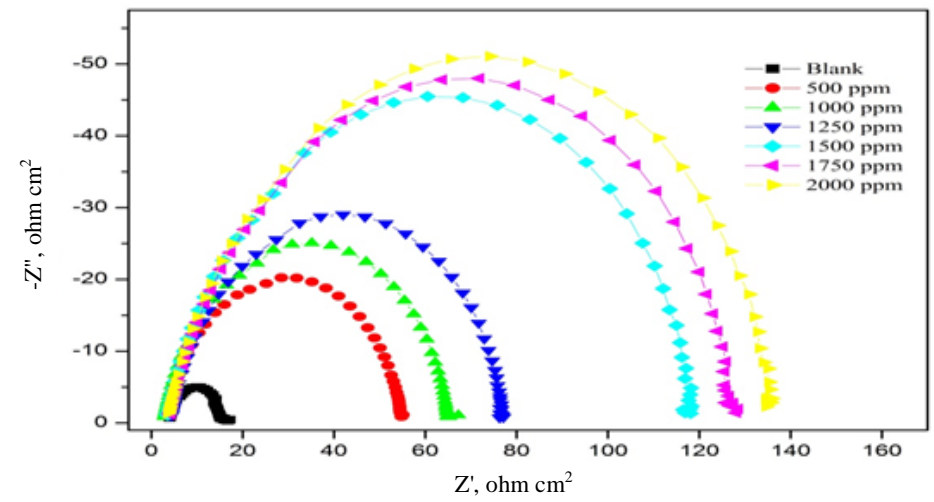

Figure 10. Nyquist plots in the absence and presence of different concentrations of $S P$ extracts in $0.5 \mathrm{M} \mathrm{HCl}$

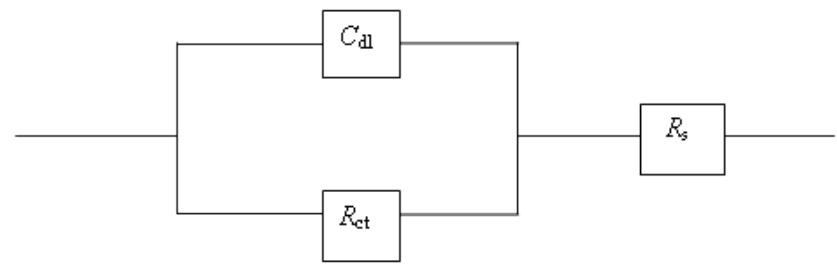

Figure 11. Electrochemical equivalent circuit used to fit the impedance spectra

$$
\eta \%=\frac{1 /\left(R_{c t}\right)_{a}-1 /\left(R_{c t}\right)_{p}}{1 /\left(R_{c t}\right)_{a}} \times 100
$$

Where, $\left(R_{\mathrm{ct}}\right)_{\mathrm{a}}$ and $\left(R_{\mathrm{ct}}\right)_{\mathrm{p}}$ are charge transfer resistances in the absence and presence of inhibitor, respectively.

From the Nquist plots (Figure 10), it is observed that the diameters of the capacitive loop increases with increasing $S P$ extracts concentrations which specify the increasing coverage of metal surface. Further, it is clear from Table 4 that by increasing the $S P$ extracts concentration, the $R_{\mathrm{ct}}$ values increases. This is because, the addition of inhibitor increases the adsorption of phytochemical constituents over the metal surface and results in the formation of a protective layer which may decrease the electron transfer between the metal surface and the corrosive medium ${ }^{41}$. On the other hand, the values of $C_{\mathrm{dl}}$ decreased with an increase in inhibitor concentration indicating that the inhibition efficiency increases. The decrease in $C_{\mathrm{dl}}$ values can be attributed to a decrease in local dielectric constant and/or an increase in the thickness of the electrical double layer which leads to an increase in the inhibition efficiency. Therefore, it is suggested that the inhibitors act by adsorption at the mild steel surface or solution interface and the change in $C_{\mathrm{dl}}$ values is caused by the displacement of water molecules by the adsorption of organic molecules on the metal surface, thus decreasing the extent of the metal dissolution ${ }^{42}$. 


\section{Scanning electron microscopy}

The action of inhibitor on corrosion process was explored from the SEM images of the polished and corroded steel surface in the absence and presence of inhibitors (Figures 12a-c). The SEM images showed the features of mild steel surface in $0.5 \mathrm{M} \mathrm{HCl}$ and $\mathrm{HCl}$ containing optimum concentration of SP extracts. Closer examination of the SEM figures revealed that the surface of the specimen immersed in free acid appeared to be corroded uniformly and the corroded damage was present everywhere. The specimen immersed in the inhibited solution was in better condition having smooth surface compared to the surface immersed in $0.5 \mathrm{M}$ $\mathrm{HCl}$ alone. This shows the formation of a protective film over the surface of the mild steel in the presence of the inhibitor.

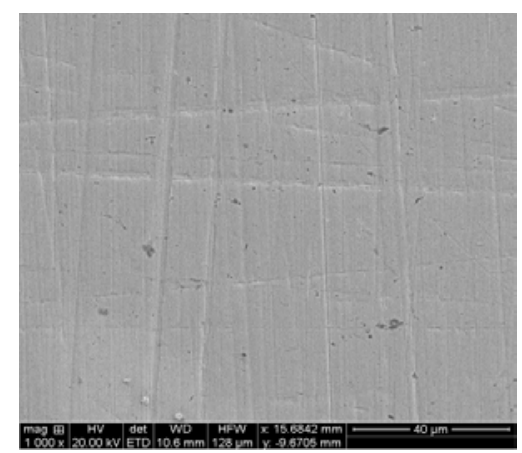

Figure 12. SEM images of mild steel in $0.5 \mathrm{M}$ $\mathrm{HCl}$ solution after $6 \mathrm{~h}$ of immersion at $30^{\circ} \mathrm{C}$ (a) Before immersion (polished)

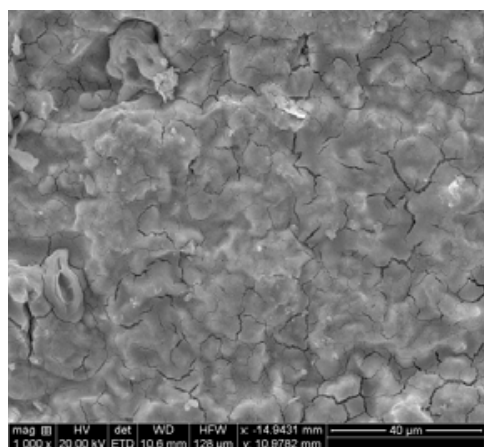

Figure 12(b). After immersion without inhibitor

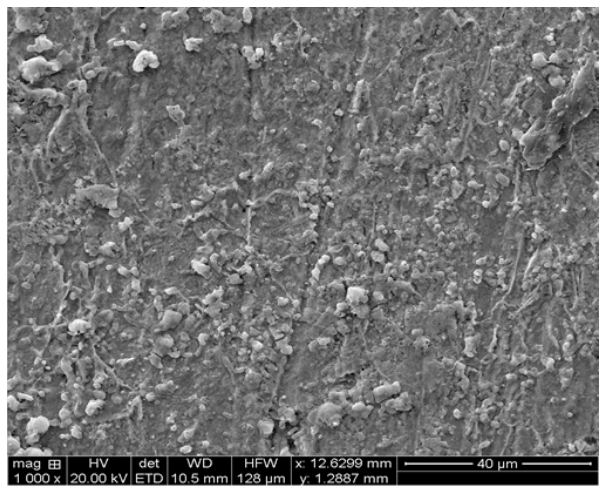

\section{Conclusion}

Figure 12(c). With 2000 ppm SP extracts

1. $S P$ extracts is an efficient corrosion inhibitor for mild steel in $0.5 \mathrm{M} \mathrm{HCl}$ medium.

2. The increase in inhibition efficiency as a function of concentration is dealing with adsorption phenomenon, and the SP extracts obeys the Langmuir adsorption isotherm.

3. The $S P$ extracts behaved as mixed type of inhibitor.

4. EIS results revealed that, as the inhibitor concentration increased the charge transfer resistance increased and the double layer capacity decreased.

5. All the results obtained from EIS, polarization and weight loss are in good agreement with each other. 


\section{Acknowledgment}

Authors would like to thank Dr. Arthoba Naik and Basavanna S, Department of Chemistry, Kuvempu University, Shankaraghatta, Shimoga for their help to carryout electrochemical experiments.

\section{References}

1. Bethencourt M, Botana F J, Calvino J J and Marcos M, Corros Sci., 1998, 40, 1803-1819.

2. Arenas M A, Conde A and De Damborenea J, Corros Sci., 2002, 44, 511-520.

3. Cano E, Pinilla P, Polo J L and Bastidas J M, Mater Corros., 2003, 54, 222-228.

4. $\quad$ Dong-Jin C, Yong-Wook K and Jung-Gu K, Mater Corros., 2001, 52, 697-704.

5. Moretti G, Guidi F and Grion G, Corros Sci., 2004, 46, 387-403.

6. $\quad$ Abd El-Maksoud S A, Int J Electrochem Sci., 2008, 3, 528-555.

7. Ajmal M, Mideen A S and Quraishi M A, Corros Sci., 1994, 36, 79-84.

8. Hosary A A, Saleh R M and Eldin A M S, Corros Sci., 1972, 12, 897-904.

9. Raja P B and Sethuraman M G, Matt Lett., 2008, 62, 113-116.

10. Oguzie E E, Corros Sci., 2008, 50, 2993-2998.

11. Lebrini M, Robert F, Blandinieres P A and Roos C, Int J Electrochem Sci., 2011, 6(7), 2443-2460.

12. Sharma M K, Arora P, Kumar S, Mathur S P and Ratnani R, Corros Eng Sci Technol., 2008, 43, 213-218.

13. Oguzie E E, Port Electrochem Acta., 2008, 26, 303-314.

14. Gopiraman M, Sakunthala P, Kanmani R, Alex R V and Sulochana N, Ionics., 2011, 17, 843-852.

15. Abiola O K and Otaigbe J O E and Kio O J, Corros Sci., 2009. 51,1879.

16. Eddy N O, Port Electrochim Acta., 2009, 27(5), 579-589.

17. Umoren S A, Obot I B, Ebenso E E and Obi-Egbedi N O, Port Electrochim Acta, 2008, 26(2), 199-209.

18. Quraishi M A, Singh A, Singh V K, Yadav D K and Singh A K, J Mat Chem Phys., 2010, 122,114-122.

19. Lahhit N, Bouyanzer A, Desjobert J M, Hammouti B, Salghi R, Costa J, Jama C, Bentiss, F and Majidi L, Port Electrochem Acta, 2011, 29, 127-138.

20. Obot I B and Obi-Egbedi N O, J Appl Electrochem., 2010, 40(11), 1977-1983.

21. Badiea A M and Mohana K N, J Mater Eng Perform., 2009, 18, 1264-1271.

22. Ambrish S, Ishtiaque A, Singh V K and Quraishi M A, J Solid State Electrochem., 2011, 15(6), 1087-1097.

23. Lomnitski L, Bergman M, Nyska A, Ben-Shaul V and Grossman S, Nutr Cancer., 2003, 46(2), 222-231.

24. Schorr M and Yahalom J, Corros Sci., 1972, 12(11), 867-868.

25. Putilova I N, Balezin S A and Barannik U P, Metallic Corrosion Inhibitor, Pergamon Press, New York, USA, 1960.

26. Lebrini M, Robert F and Roos C, Int J Electrochem Sci., 2010, 5, 1698-1712.

27. Lebrini M, Robert F, Lecante A and Roos C, Corros Sci., 2011, 53(2), 687-695.

28. Moretti G, Quartaronr G, Tassan A and Zingales A, Electrochim Acta, 1996, 41(13), 1971- 1980.

29. Abd El-Rehim S S, Ibrahim M A M and Khaled K F, Mater Chem Phys., 2001, 70(3), 268-273.

30. Guan N M, Xueming L and Fei L, Mater Chem Phys., 2004, 86, 59-68. 
31. Martinez S and Stern I, Appl Surf Sci., 2002, 199, 83-89.

32. Fouda A S, El-Taib Heakal F and Radwan M S, J Appl Electrochem., 2009, 39(3), 391-402.

33. Machnikova E, Whitmire K H and Hackerman N, Electrochim Acta, 2008, 53, 6024-6032.

34. Ashassi-Sorkhabi H and Eshaghi M, Mater Chem Phys., 2009, 114, 267-271.

35. Bentiss F, Lebrini M and Lagrenee M, Corros Sci., 2005, 47(12), 2915-2931.

36. Mertens S F, Xhoffer C, Decooman B C and Temmerman E, Corrosion., 2000, 53(5), 381-388.

37. Bentiss F, Legrenee M, Traisnel M and Homez J C, Corros Sci., 1999, 41(4), 789-803.

38. Martinez S and Metikos-Hucovic M, J App Electrochem., 2003, 33, 1137-1142.

39. Ferreira E S, Giancomelli C, Giacomelli F C and Spinelli A, Mater Chem Phys., 2004, 83, 129-134.

40. Li W H, He Q, Zhang S T, Pei C L and Hou B R, J Appl Electrochim., 2008, 38, 289295.

41. Tang Y, Yang X, Yang W, Wan R, Chen Y and Yin X, Corros Sci., 2010, 52, 1801-1808.

42. Mc-Cafferty E and Hackerman N, J Electrochem Soc., 1972, 119, 146-152. 